Nadwa : Jurnal Pendidikan Islam

Vol. 13, No.2 (2019)

Accredited by Ristekdikti based on Decree No. 51/E/KPT/2017

DOI : 10.21580/nw.2019.13.2.5086

\title{
Moderation Of Islamic Education As An Effort To Prevent Radicalism (Case Study of FKUB Singkawang City, Kalimantan, Indonesia)
}

\author{
Asrip Widodo \\ MAN Singkawang Kalimantan Barat, Indonesia \\ asripwic@gmail.com
}

\begin{abstract}
Radicalism threatens harmony and unity. We need a holistic deradicalization effort by various elements of the nation. One element that has a strategic role is the Forum for Religious Harmony (FKUB). The study was conducted to reveal the role of FKUB Singkawang City in campaigning for moderation of Islamic education for the community as an effort to prevent radicalism, thus delivering this city as the number one most tolerant city in Indonesia. The method used is a qualitative field (Field Research), researchers go directly to the field to obtain data and information from data sources. Data were collected through direct interviews with the Chairperson of FKUB Singkawang City, FKUB documentation, Social Media and direct observation to the research location. The results showed that FKUB was able to realize moderation of Islamic education outside of educational institutions with dialogue and advocating strategic.
\end{abstract}

Keywords: Moderation, Islamic Education, FKUB Singkawang

\begin{abstract}
Abstrak
Radikalisme mengancam harmoni dan persatuan. Kita membutuhkan upaya deradikalisasi holistik oleh berbagai elemen bangsa. Salah satu elemen yang memiliki peran strategis adalah Forum Kerukunan Umat Beragama (FKUB). Studi ini dilakukan untuk mengungkap peran FKUB Kota Singkawang dalam mengkampanyekan moderasi pendidikan Islam bagi masyarakat sebagai upaya mencegah radikalisme, sehingga menjadikan kota ini sebagai kota nomor satu yang paling toleran di Indonesia. Metode yang digunakan adalah bidang kualitatif (Field Research), peneliti pergi langsung ke lapangan untuk memperoleh data dan informasi dari sumber data. Data dikumpulkan melalui wawancara langsung dengan Ketua FKUB Kota Singkawang, dokumentasi FKUB, Media Sosial dan observasi langsung ke lokasi penelitian. Hasil penelitian menunjukkan bahwa FKUB mampu mewujudkan moderasi pendidikan Islam di luar lembaga pendidikan dengan dialog dan advokasi strategis.
\end{abstract}

Kata Kunci: Moderasi, Pendidikan Islam, FKUB Singkawang

ISSN 1979-1739 (P) ; ISSN 2502-8057 (E).

(C) 2019 Nadwa : Jurnal Pendidikan Islam | UIN Walisongo.

Accredited by Ristekdikti based on Decree No. 51/E/KPT/2017

http://journal.walisongo.ac.id/index.php/nadwa 


\section{Introduction}

Society is not just a group of individuals who form a social community but is also a subject of education among its citizens. A community member can educate other members or learn from other members. This is explained in the hadith:

"One day Rasulullah SAW preached and praised the Muslim groups well, then said:" Why do many people not want to give understanding to their neighbors, do not teach them, do not give them warnings and do not prevent them. And why many people don't want to learn from their neighbors, don't take lessons and warnings from them. By Allah, let a people teach their neighbors, give understanding and warning to them, or I will speed up their torment. "(HR.Thabrani). 1

This Hadith explains that the teaching-learning process can take place even if only between neighbors or community members. With this teaching-learning process community members can work together and will benefit from other members while also showing that humans are social creatures who cannot possibly live alone. Al-Faraby 2 explains that humans gather with each other because they need each other. Through this togetherness and social association they will be able to reach perfection and happiness.

Ibn Khaldun 3 states that social life is a dharuriy (axiomatic) affair. Because humans are social creatures.

Indonesian Republick Law No. 20 of 2003 concerning National Education4 states that education is not only in the form of formal education but also non-formal, namely communitybased education (General Provisions Article 1 number 16 ). Education can take place in a group or somewhere even though it is not an educational institution. Even only through cyberspace education can take place. The color of education

1 Abdullah Nasih Ulwan, Pendidikan Anak Dalam Islam, Terj Miri, Jamaludin, Drs, Lc, Pustaka Amani Jakarta, 2002;310

2 Al-Farabi. Arā'Ahl al-Madīnah al-Fādila, Beirut: Dar al-Iraq, 2002:112

3 Ibnu Khaldun, Mukaddimah, Tahqiq Abdullah Muhammad alDarwisy,Damsyiq, Dar Ya'rib,2004:137

4 Undang- Undang Republik Indonesia No.20 Tahun 2003, Sistem Pendidikan Nasional, Bandung : Citra Umbara,2003 
received by the community will shape the personality of the community concerned. If the color level received violent society will tend to behave like into hard late vice versa. Therefore moderation of education for the community is very urgent to be implemented and campaigned so that the Islamic mission of rahmatan lil 'alamin and respect for differences by maintaining each character can be realized.

People who are less sensitive to acts of violence will be permissive in the event of violent behavior. This is of course very dangerous to the peace and unity of the Republic of Indonesia which has progress. Such a rapid development of society has an impact on the social, political, religious, cultural, and outlook on life of the community concerned. One of them is a culture of violence (radicalism) that grows in various regions and often triggers theoretical actions.

Acts of terrorism which is a continuation of radicalism are still happening. Among the examples is the bomb terror at Surabaya Church. The incident of terror that befell the citizens of Surabaya, especially for Christians in the Indonesian Christian Church, the Santa Maria Church, and the Pentecostal Church made the whole community grieve and strongly condemned the practice of terrorism which had been a heavy enemy of the government. As reported by Tempo.co (05/13/18) suicide bombings in three churches in Surabaya have claimed 49 lives, 9 people have died and 40 have been injured. According to Surabaya Wakapolrestabes report, Ajun (Chief Commissioner Benny Pramono) allegedly bombs were detonated by a family involving his wife and child. After the bombing in three churches, aftershock continued to occur, namely in the Wonocolo Flats, Sidoarjo (05/13/18) at $20.30 \mathrm{WIB}$, and at the Big City Police Headquarters (Mapolrestabes) Surabaya, Monday (14/05/18) on 10:05 a.m. Previously there was also an action at Mako Brimob (05/10/18), there were two young women who were suspected of carrying out stabbing actions against members of the Mobile Brigade as reported by the Public Information Bureau of the Public Relations Division of 
the National Police Public Relations Brigadier General M. Iqbal.5

Radicalism does not only grow in one place, but various aspects of life can become fertile ground for its growth and development. Likewise with the Islamic education side. Radical understanding of religion comes from radical education. According to John Locke with Tabularasa theory (candle table)6 children are born in a state like blank paper or wax-covered tables for which there is no writing, the next color depends on the person who will color it. Likewise students or students, what they receive is what will shape their character.

Ibn Khaldun 7 considers that the child is born to carry a latent nature (hidden) and will incarnate in the form of good or bad depending on the environment that affects it. If a person is formed with a good environment, it will produce a good society, but if formed with a bad environment, that society will be bad.

One element of the environment that forms community behavior is education. The behavior of some members of the community showing a dual attitude between observing worship and carrying out theoretical actions made many think, examine and conduct research on what happened. Because it is impossible for personal piety to contradict social piety. Islamic education is in the spotlight. Whether the education they have received so far has indeed taught radicalism and has had a direct influence on the actions of theorists, eventually becoming the object of debate and research by various groups.

From any side of the research carried out, what is certain is that radicalism has become an understanding that threatens harmony, and unity. So joint efforts to tackle radicalism need to be done together and programmed holistically involving various elements and means. In the field of education, early detection and information on the dangers of radicalism must be carried

5 Fuadi Isnawan, "Program Deradikalisasi Radikalisme Dan Teorisme Melalui Nilai-Nilai Luhur Pancasila," Fikri 3, no. 1 (2018): 43, https://doi.org/http://doi.org/10.25217/jf.v3i1.275.3-4

6 Jalaludin dan Abdullah Idi,Filsafat Pendidikan Manusia, Filsafat dan Pendidikan, AR-RUZZ MEDIA, Jogjakarta, Cet 1.2007.153-154

7 Ibnu Khaldun, Mukaddimah, Tahqiq Abdullah Muhammad alDarwisy,Damsyiq, Dar Ya’rib,2004:248 
out. Revamping the curriculum, multicultural understanding and plurality for educators and educating the public on the importance of religious moderation is very urgent to do. On the other hand, education for the wider community must also be carried out and given contents that refer to counter radicalism.

Moderation of Islamic education for the community is the right solution to counter radicalism so that terrorism can be prevented. Because after all the community views that some elements of Muslims are perpetrators of acts of terrorism that occurred in this country so that the stigma that Islam is identical with theory is difficult to avoid, although it must be distinguished between the individual and the teachings.

This study seeks to examine the role of the Singkawang City Religious Harmony Forum (FKUB) in campaigning for moderation of Islamic education for the community as an effort to prevent radicalism. Because FKUB Singkawang City has a big hand in realizing harmony, harmonization, and tolerance among religious people in Singkawang City so that it will deliver this City as the number one most tolerant city in Indonesia. Namely on Friday December 7, 2018 Singkawang was named by the Setara Institute as the Number One Most Tolerant City in Indonesia defeating the big cities of Jakarta and Surabaya8.

\section{Method}

This study uses a qualitative field approach (Field Research), researchers go directly to the field to obtain data and information from data sources. Data were collected through direct interviews with the Chairperson of FKUB Singkawang City, FKUB documentation, Social Media and direct observation to the research location. The research procedures that researchers use are descriptive qualitative, namely research conducted by observing the situation in obtaining information and data according to the situation that occurs in the field. The

${ }_{8}$ VOA Indonesia, SETARA Institute: Singkawang, Kota Paling Toleran Se-Indonesia, https://www.voaindonesia.com/a/setara-institute-singkawangkota-paling-toleran-se-indonesia/4690956.html, diakses tanggal 21/12/2019 pukul 20:21; dan TEMPO.co, Belajar dari Singkawang, Kota Paling Toleran 2018https://nasional.tempo.co/read/1153831/belajar-dari-singkawang-kotapaling-toleran-2018/full\&view=ok , diakses tanggal 21/12/2019 pukul 20:21 
qualitative method is also called naturalistic research because the research is conducted to examine natural conditions, where the researcher as a key instrument, data source sampling is done by purposive sampling, various data collection techniques (triangulation or combination), data analysis are inductive and the results of research emphasize more on the meaning than the generalization9.

\section{The Concept of Moderation and Radicalism}

According to the Big Indonesian Dictionary the notion of "radical" as 1) fundamental (to the principle); 2) (in political terms) very strongly demanding changes (laws, governance); 3) advance in thinking and acting. 10 So, radical does not have to mean negative but also has a positive side.

Mukhtar Sarman11 explains that the radical comes from the word radix (Latin meaning tree root, as a figure of something to hold on tight). Radicalism is the ideology or flow that wants social or political change or renewal in a drastic way. Radical people tend to impose their exclusive beliefs on others. They are usually impatient waiting for a gradual change because they base their understanding on "the conditions that should be" rather than the actual situation. This tendency causes misunderstandings for ordinary people as if radicals are considered the same as idealists. Though idealistic people are people who think and act based on an ideal vision, in contrast to radical people.

When radicalism is pinned on Muslims who have a radical understanding, the term radical Islam is born. Zaki Mubarak in Noermala Sary explained that the criteria of 'radical Islam' can be mentioned as groups that have high ideological and fanatical beliefs that they strive to replace the order of values and the ongoing system, in their activities they often use violent actions,

9 Sugiyono, Metode Penelitian Pendidikan ,(Bandung: Alfabeta, B andung, 2015,15

10 Departemen Pendidikan Nasional, Kamus Besar Bahasa Indonesia, Jakarta: Balai Pustaka, 2002, hlm 919

${ }_{11}$ Mukhtar Sarman, Meretas Radikalisme, Menuju Masyarakat Inklusif, LKiS, Yogyakarta,2018:20-22 
even do not close the possibility of being rude to the activities of other groups that are considered contrary to their beliefs, socioculturally and socio-religiously, radical groups have strong group ties and display distinctive characteristics of selfappearance and ritual. The group 'radical Islam' often moves guerrilla, although many also move openly.12

Terrorism comes from embryo radicalism. Radicalism by BNPT definition13_ is an attitude that craves total change and is revolutionary by overturning existing values drastically through violence and extreme actions. There are several characteristics that can be recognized from a radical attitude and understanding. 1) intolerant (do not want to respect the opinions and beliefs of others), 2) fanatic (always feels right himself; think others are wrong), 3) exclusive (distinguish themselves from Muslims in general) and 4) revolutionary (tend to use violent means to reach the goal).

Radicalism arises because of impatience in dealing with differences. Difference is seen as a mistake that must be eradicated. The terms heresy, heresy, infidelity, and taghout are easily brought out and triggered acts of violence in the name of religion. Radicalism is preceded by fanaticism and causes terrorism. Fanaticism only views one truth and ignores another truth. Differences that are inevitable and sunnatullah ignored. Though God created humans in different ways to get to know one another and then understand each other rather than be hostile. A person's glory is not seen from differences in race, race, color and class but rather from his piety (QS. Al-Hujurat / 49: 13).14 Besides fanaticism, according to Mukhtar Sarman the problem of intolerance that occurs in society is generally

12 Noermala Sary, "Mencegah Penyebaran Paham Radikalisme Pada Sekolah," Manthiq 2, no. 2 (2017): 193.

13 BNPT, Strategi Menghadapi Paham Radikalisme-Terorisme-ISIS, https://belmawa.ristekdikti.go.id/wp-content/uploads/2016/12/Strategi-

Menghadapi-Paham-Radikalisme-Terorisme.pdf diakses tanggal 16/01/2020 pukul 14:22

14 Departemen Agama RI, Al-Qur'an Dan Terjemahnya, Edisi Tahun 2002,518 
understood as a further consequence of the emergence of radical notions. 15

Even though terrorism was born from radicalism, but having a radical attitude and understanding does not necessarily make a person fall into terrorism understanding and action. There are other factors that motivate someone to join the terrorism network. Motivation according to BNPT is caused by several factors. First, domestic factors, namely domestic conditions such as poverty, injustice or feeling disappointed with the government. Second, international factors, namely the influence of the foreign environment that provides the driving force for the growth of religious sentiment such as global injustice, arrogant foreign policy, and modern imperialism of the superpower. Third, cultural factors which are closely related to shallow religious understanding and narrow and lexical interpretation of the holy book (harfiyah). Radical attitudes and understandings and motivated by various factors above often make a person choose to join in terrorist acts and networks. 16

According to Horace M. Kallen 17 radicalism is characterized by three general trends:

1. Radicalism is a response to ongoing conditions. The response appears in the form of evaluation, rejection, or even resistance

2. Radicalism does not stop with rejection, but instead tries to replace other orders. These characteristics show that radicalism contains a program or world view of its own. Radicals strive to make the order a substitute for an existing order.

15 Mukhtar Sarman, Meretas Radikalisme, Menuju Masyarakat Inklusif, LKiS, Yogyakarta,2018:20-22

16 BNPT, Strategi Menghadapi Paham Radikalisme-Teorisme-ISIS, https://belmawa.ristekdikti.go.id/wp-content/uploads/2016/12/Strategi-

Menghadapi-Paham-Radikalisme-Terorisme.pdf ,diakses tanggal 16/01/2020 pukul 14:22

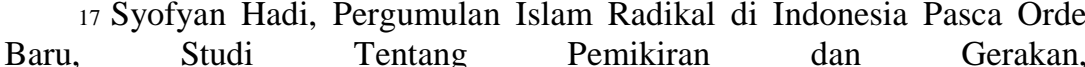
https://www.academia.edu/19759203/PERGUMULAN_ISLAM_RADIKAL DI_INDONESIA_PASCA_ORDE_BARU_Studi_Tentang_Pemikiran_dan Gerakan, diakses tanggal 21/01/2020, pukul 09.14, 6-7 
3. Radicalists have strong beliefs about the truth of the program or ideology they carry. In radical social movements fighting for beliefs that they think is right with emotional attitudes that lead to violence.

Theoretically, radicalism appears in the form of acts of rejection, resistance, and the desire of certain communities so that the world is changed and arranged in accordance with its religious doctrine.

Mahmudati (2014: 30), in Masnur, et.al (2018) explained that there are four characteristics of radicalism, namely: first, intolerance and not respecting the opinions or beliefs of others. Second, fanatical attitudes, namely attitudes that justify themselves and blame others. Third, exclusive attitude, which is a closed attitude and trying to be different from the habits of many people. Fourth, a revolutionary attitude, namely the tendency to use violence in achieving goals. 18

If examined the reasons for the fertility of radicalism in Indonesia, there are two factors, namely internal factors and external factors. According to Fuadi Isnawan internal factors are caused by the understanding of religious texts that are narrow, rigid, fanatical and hard. While external factors are caused by Western political, economic and cultural hegemony which is considered to distort the traditionalism of radicalists. In addition, psychological factors also affect them, where feelings have the ability and meaning to do something to make them rise to move. There is optimism in the minds of those who move to take action to change what happens in their environment which is considered not in accordance with what they should expect.19

Radical groups want fundamental social change or renewal of religion with a new system or value system that they believe. Not only is discourse or thought to a certain extent this

18 Masnur alam, "PENERAPAN PENDIDIKAN ISLAM ANTIRADIKALISME DALAM MERAJUT HARMONI: Suatu Tinjauan Di Kota Sungai Penuh Jambi," Lentera Pendidikan: Jurnal Ilmu Tarbiyah dan Keguruan, 2018, https://doi.org/10.24252/lp.2018v21n2i11.

19 Isnawan, "Program Deradikalisasi Radikalisme Dan Teorisme Melalui Nilai-Nilai Luhur Pancasila."9-11 
understanding can manifest in the form of movement or action on the ground.

In line with Fuadi Isnawan, Masnur Alam mentioned two factors triggering radicalism, namely internal factors of economic and social political inequality, added with heterogeneity of the community, discriminatory occurrence, then only accompanied by ethnicity and religious diversity, the emergence of diversity in the flow, such as extreme understanding who always think their group is right while others are wrong. Militants namely violence in the name of religion, as well as fundamentalists, exclusives, and radicals who always claim that their religion is right, blame others, and "disbelieve each other."

In addition, external factors also quite influence the situation of Indonesia, namely various movements rooted in the Middle East or other places that want to establish the Khilafah, a single universal Islamic political entity, both "peacefully" and "radically" and terrorism increasingly appearing openly. Like the emergence of militant Islamic State of Iraq and Syria (ISIS) whose accomplices have spread to many countries in the world including Indonesia.20

\section{Deradicalization Efforts}

Considering the great danger posed by radicalism, effective and holistic prevention and handling efforts are needed. If it is still in the form of understanding, then moderation of understanding is the answer. But if it has become an act of terrorism, it is not enough just to moderate understanding. Legal action and efforts to deradicalize must be done. Violence must be faced with tenderness. Radicalism must be faced with deradicalization or moderation. Because radicalism often departs from an understanding of the texts of religious teachings, the moderation of the understanding of Islam through education is very necessary. Because education plays a role in conveying

20 Masnur alam, "PENERAPAN PENDIDIKAN ISLAM ANTIRADIKALISME DALAM MERAJUT HARMONI: Suatu Tinjauan Di Kota Sungai Penuh Jambi." 
religious messages to students and the community. The implementation of education carried out through moderate messages will produce a moderate understanding. Conversely, if done through radical messages will produce a radical understanding. The character of Islam that is tawassuth, i'tidal, and tawazun strongly opposes the radical attitude in religion both right radical and left radical. Because it is contrary to the benefit of humans while religion itself is present to realize that benefit that is protecting religion, protecting souls, protecting intellect, protecting offspring, and protecting property. 21

As the spearhead of theorizing prevention, the National Counterterrorism Agency (BNPT) uses the first two strategies, counter radicalization, namely efforts to instill Indonesian values and non-violent values. In the process this strategy is carried out through both formal and non-formal education. Counter-radicalization is directed at the general public through collaboration with religious leaders, educational leaders, community leaders, traditional leaders, youth leaders and other stakeholders in providing national values. The second strategy is deradicalization. The field of deradicalization is aimed at sympathizers, supporters, nucleus and militants carried out both inside and outside prison. The purpose of deradicalization is that; core groups, sympathetic militants and supporters abandoned the methods of violence and terror in fighting for their mission and moderate their radical ideas in line with the spirit of moderate Islamic groups and in line with national missions that strengthened the Republic of Indonesia.22

In addition to the efforts undertaken by BNPT, efforts to deradicalize community religious understanding by other elements are also urgent. For the past four years the government through the Ministry of Religion has used the term moderation to replace deradicalization. Because education for the

21 Abu Zahrah, Ushul Fiqih, terj.Saefullah Ma'shum at.all,Pustaka Firdaus, Jakarta, Cetakan kesepuluh, 2007: 425). Juga al-Amidi, al-Ahkam, Juz 3, hal 274, Maktabah Syamilah

22 BNPT, Strategi Menghadapi Paham Radikalisme-Teorisme-ISIS, https://belmawa.ristekdikti.go.id/wp-content/uploads/2016/12/Strategi-

Menghadapi-Paham-Radikalisme-Terorisme.pdf, diakses tanggal 16/01/2020 pukul 14:22 
community has an influence on the growth and development of radicalism, the moderation of Islamic education is urgent to do.

Etymologically, moderation comes from Latin moderato, which means moderation (not excess and not lack), self-control (from attitudes of strengths and weaknesses). According to the Big Indonesian Dictionary moderation means: 1. Violence reduction, 2. Avoidance of extremes. Whereas moderate means: 1. Always avoid extreme behavior or disclosure; 2. Tend towards the dimension or middle ground. If it is said, "his views are quite moderate, " the sentence means he considers the views of the other party. 23

In English, the word moderation means average (average), core (core), standard (standard), or non-aligned (impartial). In general, moderate means promoting balance in terms of beliefs, morals, and character, both when treating others as individuals, and when dealing with state institutions. Whereas in Arabic, moderation is known as the word wasath or wasathiyah, which has the equivalent meaning of the words tawassuth (middle), i'tidal (fair), and tawazun (balanced). People who apply the principle of wasathiyah can be called wasith. In Arabic too, the word wasathiyah is interpreted as "the best choice". Whatever words are used, they all imply the same meaning, which is fair, which in this context means choosing the middle ground position among the various extreme choices (tatharruf, ghuluw, tasyaddud). 24

So being moderate means avoiding extremism, both extreme right and extreme left. The right extreme will cause someone to exceed the limits of religious provisions, the extreme left will cause someone to be indifferent and weak in practicing religion.

23 Departemen Pendidikan Nasional, Kamus Besar Bahasa Indonesia, Edisi keempat, Jakarta,PT Gramedia Pustaka Utama, 2008:924

24 Kementerian Agama RI, “Moderasi Beragama," Badan Litbang dan Diklat Kementerian Agama RI Gedung Kementerian Agama RI Jl.MH.Thamrin No 6 Lt.2 Jakarta Pusat, 2019.15-16 


\section{The Role of FKUB in Singkawang City in Moderation of Islamic Education}

To realize religious moderation, the government through the Ministry of Religion of the Republic of Indonesia provides four indicators namely 1) national commitment; 2) tolerance; 3 ) non-violence; and 4) accommodating to local culture. These four indicators can be used to identify how strong religious moderation is practiced by someone in Indonesia, and how much vulnerability they have. This vulnerability needs to be recognized so that we can identify and take the right steps to strengthen religious moderation. 25

With these four indicators, Islamic education needs to be carried out on this basis. Religious texts cannot be changed but the understanding of the texts is reinterpreted so that the religious understanding is moderated. Form al the moderation of education I slam done in formal educational institutions. But in the community can be done by other elements such as the Forum for Religious Harmony.

The Forum for Religious Harmony (FKUB) as a forum to establish and strengthen harmony among people of various religions has a strategic role in the effort to moderate Islamic education in the community, including through education to the general public, certain groups in the community, even synergizing with institutions. educational institutions.

The Religious Harmony Forum was formed based on Joint Regulation of the Minister of Religion and the Minister of the Interior (PBM) No 9 and 8 of 2006 . FKUB was established to initiate harmony between religions. The diversity of cultures, religions, customs and ethnicities as Indonesia's wealth must be maintained so as not to be tarnished by conflicts between tribes, religions, races, and groups. The spirit that is built is to live together in diversity. In social life, the existence of regulations is indeed a necessity. However, in matters of religion the rules cannot reach all matters relating to religious harmony. Rules are only a minimum, while harmony requires a greater willingness and ability to realize a peaceful life together. On this side FKUB can play a strategic role that is initiating dialogue and 
advocating for moderate Islamic education. Because above the rules and regulations there is dialogue and fundamental shared values which are referred to as the "Golden Rule" or reciprocity. Namely putting ourselves in the position of others. In general, these rules are formulated in the sentence: Do other people what you want others to do to you. Don't do to others what you don't want others to do to you. This golden rule exists in most religions and local wisdom although expressed in different sentences.

Golden Rule Table

\begin{tabular}{ccl}
\hline No & Religion & \multicolumn{1}{c}{ Teachings } \\
\hline 1 & Buddha & $\begin{array}{l}\text { Don't hurt people like that will hurt } \\
\text { you. Buddha, Udana-Varga 5.18 }\end{array}$ \\
\hline 2 & $\begin{array}{c}\text { Christian and } \\
\text { Catholic }\end{array}$ & $\begin{array}{l}\text { Everything that you want people to } \\
\text { do to you, do the same for them; } \\
\text { thus the law and the prophets. Jesus, } \\
\text { Matthew 7:12 }\end{array}$ \\
\hline 3 & Confucianism & $\begin{array}{l}\text { One word that summarizes the } \\
\text { principles of human good deeds ... } \\
\text { love-virtue. Don't treat others what } \\
\text { you don't like yourself. Confucius's } \\
\text { Analysis 15.23 }\end{array}$ \\
& & $\begin{array}{l}\text { This is the essence of the Dharma: } \\
\text { Don't treat others with what hurts } \\
\text { you if it is done to you. Mahabharata } \\
\end{array}$ \\
& Hinduism 1517 \\
\hline 4 & $\begin{array}{l}\text { A person does not believe before he } \\
\text { wants his brother what he wants for } \\
\text { him. Prophet Muhammad's Hadith }\end{array}$ \\
\hline 5 & Islam &
\end{tabular}


Rule it can also referred to as the attitude of compassion, and basically is an attitude of reciprocal (effort put ourselves we are in the position of the other). 26

\section{Moderation of Islamic Education as an Effort to Prevent Radicalism in Singkawang}

The city of Singkawang, West Kalimantan, although composed of various ethnicities and religions, is able to realize harmony and harmony of life so that it is far from horizontal conflicts. The Malays and Dayaks are the original inhabitants of Singkawang City and Kalimantan in general. While the migrant tribes include Javanese, Bugis, Madurese, Sundanese, Padang, Batak, Ambon and ethnic Chinese as the majority ethnic.

The symbols of moderation and harmony in this City are quite a lot. There is a Great Mosque that stands adjacent to the Tri Darma Bumi Raya Temple, AI Roundabout, Balai Serumpun Malay House that can be used for community events. Tidayu Monument (Chinese, Dayak, Malay), Naga Monument, Dayak Customary Council, Buda Religion Council, Parisada Hindu Religion, Juadah Ramadhan, Takjil Ramadhan, Ramadhan Ketupat installed in each, Green and Yellow Lanterns and now Singkawang is led by the Mayor of Women from Ramadan ethnic Chinese, Tjhai Chui Mie, SE, MH and their representatives are from the Malay ethnic group H.Irwan, M.Sc.27

Freedom of religion and expression is well maintained, assimilation occurs between different tribes so that differences do not become obstacles to respect. The principle is for you your religion and for me my religion is held firm but tolerance is still put forward. If there is a conflict, then it is resolved in stages

26 Ihsan Ali-Fauzi, dkk, Menggapai Kerukunan Umat Beragama: Buku Saku FKUB, PUSAD Paramadina,2018:8-9, Diunduh tgl 15/01/2020 pukul 12. 55

27 FKUB Kota Singkawang, Dokumen, Sepenggal Kisah Perjalananku di Kota Singkawang https://youtu.be/aeJUaCEOBYQ; diakses tanggal 19/12/2019 pukul 10:25 
from the RT level up to the higher level and all religious interests are facilitated by the City Government.28

Cultivating mutual respect is pumped by various figures. The values of religiosity and love of the state are instilled in students. If there are schools that have followers of different religions then tolerance is taught in such a way that life in the community is also carried away as when receiving lessons in school.29 This condition of Singkawang attracted the attention of Gajah Mada University to conduct FGD with FKUB Singkawang to make documentary films. 30

Based on the results of interviews with the Chairperson of FKUB Singkawang City, 31 study documentation of activities, social media studies of uploads on religious harmony in the City of Singkawang and direct observation to the research location, it is known that in order to realize moderation and counteract radicalism FKUB Singkawang City has made efforts :

1. Preparation of Religious Harmony Maintenance Program every year.

2. Conducting internal dialogue Singkawang City FKUB management.

3. Absorb and capture community aspirations related to religious harmony in the City of Singkawang

4. Recommend the results of interfaith dialogue for religious harmony including the deradicalization of radical and anarchist ideas in the City of Singkawang.

28 FKUB Kota Singkawang, Dokumen, Mata Indonesia 2017Menggenggam Persatuan, Menjunjung Keberagaman SEG 2,https://youtu.be/cLe8cWsuUR4, diakses tanggal 19/12/2019 pukul 10:26

29 FKUB Kota Singkawang, Dokumen, Menggali Nilai Cinta dan Toleransi Sebuah Negeri Seg.3,https://youtu.be/6GHR9zER2ho, diakses tanggal 19/12/2019 pukul 10:26

30 FKUB Kota Singkawang, Dokumen, UGM Lakukan FGD Dengan FKUB Singkawang Untuk Film Dokumenter https://s.docworkspace.com/d/AHUZw3Gqqd4worfp9tWmFA, diakses tanggal 19/12/2019 pukul 10:30

31 Wawancara dengan Ketua FKUB Kota Singkawang, Baharuddin, SH, tanggal 19 Desember 2019 
5. Socialization of legislation concerning religious harmony and deradicalization to educational institutions, religious institutions and religious instructors in Singkawang City.

6. The spread of multiculturalism education and tolerance to the community, even FKUB Singkawang City has become a resource person in Taiwan, UGM, Kuala Lumpur and others.

7. Collaborate through socialization with teachers, madrasa principals, and principals at Madrasah Aliyah / SMA and Superintendent levels because they are KBM (Teaching and Learning) actors.

8. Documentary filmmaking in collaboration with UGM through FGD.

9. Publish activities to social media as a form of information to the public.

This effort is important because Singkawa City is a miniature of a country with various ethnicities and followers of different religions. The proportion of followers of religion in Singkawang City can be seen in the following table:

Table of Religious Adherents in the City of Singkawang

\begin{tabular}{cccc}
\hline NO & SUB-DISTRICT & RELIGION & AMOUNT \\
1 & Middle & Islam & 59,788 \\
& Singkawang & & \\
& & Christian & 2,414 \\
& & Catholic & 1,806 \\
& Hindu & 13 \\
& Buddha & 13,673 \\
& & Confucianism & 117 \\
& & Islam & 31 \\
\hline 2 & West & & 19,448 \\
& Singkawang & Christian & 4044 \\
& & Catholic & 4,318 \\
& & Hindu & 32 \\
& & Buddha & 40,505 \\
& & Confucianism & 359 \\
& & The flow of trust & 72 \\
\hline
\end{tabular}




\begin{tabular}{|c|c|c|c|}
\hline \multirow[t]{7}{*}{3} & East & Islam & 7,481 \\
\hline & & Chrictian & 3278 \\
\hline & & Catholic & 8.497 \\
\hline & & Hindu & 10 \\
\hline & & Buddha & 6,913 \\
\hline & & Confucianism & 27 \\
\hline & & The flow of trust & 47 \\
\hline \multirow[t]{8}{*}{4} & North & Islam & 26,935 \\
\hline & & Chriction & 224 \\
\hline & & Christian & 324 \\
\hline & & Catholic & 194 \\
\hline & & Hindu & 5 \\
\hline & & Buddha & 4,724 \\
\hline & & Confucianism & 261 \\
\hline & & The flow of trust & 40 \\
\hline \multirow[t]{8}{*}{5} & South & Islam & 23,276 \\
\hline & Singkawang & & \\
\hline & & Christian & 4,266 \\
\hline & & Catholic & 5,104 \\
\hline & & Hindu & 45 \\
\hline & & Buddha & 30,103 \\
\hline & & Confucianism & 401 \\
\hline & & The flow of trust & 30 \\
\hline \multirow[t]{9}{*}{6} & Total Number of & Islam & 136.928 \\
\hline & Singkawang & & \\
\hline & Religions in the & & \\
\hline & & Christian & 14.326 \\
\hline & & Catholic & 19.919 \\
\hline & & Hindu & 105 \\
\hline & & Buddha & 94.918 \\
\hline & & Confucianism & 1.012 \\
\hline & & The flow of trust & 220 \\
\hline
\end{tabular}

Source: FKUB Singkawang City 
With the composition of the population and religious adherents as in this table, the moderation of Islamic education becomes very urgent to realize harmony between citizens and religious communities in order to sustain national stability. Religious Moderation is very important because:

1. To uphold human values. one of the essence of the presence of religion is to preserve the dignity of mankind as a noble creature created by God, including guarding not to lose his life.

2. So that human civilization is not destroyed due to religious background conflicts.

3. Specifically in the Indonesian context, religious moderation is needed as a strategy for our culture in caring for Indonesianness.

4. Religious moderation is actually a shared moral good that is relevant not only to individual behavior, but also to the community or institution. 32

Radicalism that is allowed to destroy the four things above. Human values will be eroded by imposed personal desires, human civilization can be destroyed because of conflicts of religious background which stand on a single interpretation of religious texts that are actually multi-interpreted. Furthermore, in the context of Indonesia, it can threaten the cultural existence of different tribes because it is triggered by conflict in maintaining a culture which is considered wrong by radicals. So radicalism will not bring good for individuals, communities or even countries.

\section{Discussion}

Humans are born to bring the nature of holiness then because the influence of the natural environment changes to negative behaviors one of which is radicalism. With the rise of radicalism, there is a great danger that threatens the integrity of the Unitary Republic of Indonesia . The presence of radicalism begins with fanaticism and often results in acts of terrorism. Radicalism ignores the diversity of cultures, religions, beliefs, and understandings and seeks drastic changes to an issue.

32 RI, “Moderasi Beragama.”8-11 
To deal with radicalism requires comprehensive holistic efforts ranging from early detection of the potential of radicalism to law enforcement and enforcement. Specifically, combating terrorism and radicalism is borne by the BNPT (National Counter Terror Agency), but that does not mean it is only the duty of the BNPT. All elements that support the moderation of religious understanding and anti-radicalism must take a role for de-radicalization. Islamic education institutions can take on the role of moderating Islamic education in their institutions, social organizations can take on the role of moderation of understanding in their organizations . Likewise the forums that stand in various social lines such as the Forum for Religious Harmony (FKUB).

FKUB of Singkawang City has proven to be actively involved in the de-radicalization activities through education to other elements of society. The results achieved by the City of Singkawang won the most tolerant city award in Indonesia from the Stara Institute in 2018. FKUB became a bridge for other elements of society to deradicalize through their authority.

In connection with a moderate understanding of religion, the following values need to be instilled through education:

$\checkmark$ Understanding that differences of opinion in the field of furu'iyyah is a necessity. This is based on four cases, namely the nature of religion, the nature of language, the nature of man and the nature of life and nature. 33

$\checkmark$ Avoid the wrong bigotry, which is not seeing other than himself, not hearing except his own words, and not trusting other people outside the group or congregation where he is affiliated. From that point he departed, and in that direction he also set the finish line. He closes his mind and himself from "the others" (the others), and all humans are considered "other" outside themselves and their groupswhere he surrenders his intellect, feelings, and loyalty. That group thinks for him; determine who he should like or hate,

33 Yusuf Al-Qardhawi, Fiqih Perbedaan Pendapat cet keempat, terj.Aunur Rafiq Shaleh Tamhid, Robbani Press, Jakarta,1997, 69-81 
who he should love or be enemies with, without ever giving himself the right to contemplate, test, and discuss it. 34

$\checkmark$ Do not make fun of and think bad of others. Because it may be that people are mocked and targeted for prejudice are better than those who mock and think bad. (QS.Al-Hujurat / 49: 11-12).35

$\checkmark$ Do not criticize or stigmatize negatively towards different opinions. For example, with accusations of the makers of heresy or grave worshipers for grave pilgrims and tawasul. Because there are no Muslims who believe in a God who sincerely wants to go to hell by making heresy and worshiping the grave. Bid'ah itself is agreed to forbidden, but scholars differ in opinion in determining the types of actions that fall into the category of bid'ah due to differences in understanding the formulation of bid'ah. Because the Holy Prophet did not provide a detailed definition of what is heresy.

$\checkmark$ Dive into the opinions and reasons of other parties, do not rush to say 'there is no argument'. Because the words 'no argument' can mean three possibilities, namely there is no proof; or he does not know the proposition; or no argument but he did not $\mathrm{m}$ erima and clicking admit the proposition.

$\checkmark$ Realizing that character and unit are not only in theory but must be practiced. The Holy Prophet even explained that the person who was closest to his assembly with him on the Day of Judgment was the most moral. (HR. Tirmidhi) 36

If all elements move to build understanding in differences, radicalism can be prevented and harmony will be well realized.

34 Direktorat Urusan Agama Islam Ditjen Bimas Islam dan Penyelenggaraan Haji Departemen Agama RI, Pedoman Pembinaan Ukhuwah Islamiyah,Jakarta, 2004,199-200

35 Departemen Agama RI, Al-Qur'an Dan Terjemahnya, Edisi Tahun 2002,517

36 Imam Tirmidzi, Sunan Tirmidzi, Juz 8 hal 39, Maktabah Syamilah 


\section{Conclusion}

From the explanation above, it can be concluded that the environment can influence a person or society to take actions that are against nature like radicalism. Radicalism does not emerge suddenly but through a process that is triggered by internal and external factors. Internal factors include understanding religious texts that are rigid, old-fashioned, rigid, and assume understanding outside themselves is wrong and must be subdued. While external factors come from the political situation in the Middle East and anti-Western feelings that are considered to have eroded the traditionalism of the radicals.

To deal with radicalism, it is necessary to be together among activists of religious moderation. In the field of harmony between religious communities FKUB has a significant role to maintain harmony and tolerance in order to achieve peace and stability in society in particular and the Indonesian nation as a whole.

\section{References}

Alam, Masnur . "PENERAPAN PENDIDIKAN ISLAM ANTIRADIKALISME DALAM MERAJUT HARMONI: Suatu Tinjauan Di Kota Sungai Penuh Jambi." Lentera Pendidikan: Jurnal Ilmu Tarbiyah dan Keguruan, 2018. https://doi.org/10.24252/lp.2018v21n2i11.

Al-Amidi, al-Ahkam, Juz 3, hal 274, Maktabah Syamilah

Departemen Agama RI, Al-Qur'an Dan Terjemahnya, Edisi Tahun 2002

Departemen Pendidikan Nasional, Kamus Besar Bahasa Indonesia, Jakarta: Balai Pustaka, 2002

Direktorat Urusan Agama Islam Ditjen Bimas Islam dan

Penyelenggaraan Haji Departemen Agama RI, Pedoman

Pembinaan Ukhuwah Islamiyah,Jakarta, 2004

Al-Farabi. Arā'Ahl al-Madinah al-Fädila, Beirut: Dar al-Iraq, 2002:112

Fauzi, Ali, Ihsan, dkk, Menggapai Kerukunan Umat Beragama:

Buku Saku FKUB, PUSAD Paramadina,2018:8-9, Diunduh tgl 15/01/2020 pukul 12. 55

Isnawan, Fuadi. "Program Deradikalisasi Radikalisme Dan Teorisme Melalui Nilai-Nilai Luhur Pancasila." Fikri 3, 
no.

(2018):

43.

https://doi.org/http://doi.org/10.25217/jf.v3i1.275.

Jalaludin dan Abdullah Idi, Filsafat Pendidikan Manusia, Filsafat dan Pendidikan, AR-RUZZ MEDIA, Jogjakarta, Cet 1.2007

Khaldun, Ibnu, Mukaddimah, Tahqiq Abdullah Muhammad alDarwisy,Damsyiq, Dar Ya'rib,2004:137

Al-Qardhawi,Yusuf, Fiqih Perbedaan Pendapat cet keempat, terj.Aunur Rafiq Shaleh Tamhid, Robbani Press, Jakarta,1997,

RI, Kementerian Agama. "Moderasi Beragama.” Badan Litbang dan Diklat Kementerian Agama RI Gedung Kementerian Agama RI Jl.MH.Thamrin No 6 Lt.2 Jakarta Pusat, 2019.

Sarman, Mukhtar, Meretas Radikalisme, Menuju Masyarakat Inklusif, LKiS, Yogyakarta,2018:20-22

Sary, Noermala. "Mencegah Penyebaran Paham Radikalisme Pada Sekolah." Manthiq 2, no. 2 (2017): 191-200.

Sugiyono, Metode Penelitian Pendidikan ,(Bandung: Alfabeta, Bandung,2015

Tirmidzi, Imam, Sunan Tirmidzi, Juz 8 hal 39, Maktabah Syamilah

Undang- Undang Republik Indonesia No.20 Tahun 2003, Sistem

Pendidikan Nasional, Bandung : Citra Umbara,2003

Ulwan,Nasih, Abdullah, Pendidikan Anak Dalam Islam, Terj Miri, Jamaludin, Drs, Lc, Pustaka Amani Jakarta, 2002

Wawancara dengan Ketua FKUB Kota Singkawang, Baharuddin, SH, tanggal 19 Desember 2019 pukul 09:30

Zahrah, Abu, Ushul Fiqih, terj.Saefullah Ma'shum at.all,Pustaka Firdaus, Jakarta, Cetakan kesepuluh, 2007: 425).

BNPT, Strategi Menghadapi Paham Radikalisme-TeorismeISIS, https://belmawa.ristekdikti.go.id/wpcontent/uploads/2016/12/Strategi-Menghadapi-Paham-

Radikalisme-Terorisme.pdf diakses tanggal 16/01/2020 pukul 14:22

FKUB Kota Singkawang, Dokumen, Sepenggal Kisah Perjalananku di Kota Singkawang https://youtu.be/aeJUaCEOBYQ; diakses tanggal 19/12/2019 pukul 10:25 
FKUB Kota Singkawang, Dokumen, Mata Indonesia 2017Menggenggam Persatuan, Menjunjung Keberagaman SEG 2, https://youtu.be/cLe8cWsuUR4, diakses tanggal 19/12/2019 pukul 10:26

FKUB Kota Singkawang, Dokumen, Menggali Nilai Cinta dan Toleransi Sebuah Negeri Seg.3, https://youtu.be/6GHR9zER2ho, diakses tanggal 19/12/2019 pukul 10:26

FKUB Kota Singkawang, Dokumen, UGM Lakukan FGD Dengan FKUB Singkawang Untuk Film Dokumenter, https://s.docworkspace.com/d/AHUZw3Gqqd4worfp9tWmFA, diakses tanggal 19/12/2019 pukul 10:30

Syofyan Hadi ,Pergumulan Islam Radikal di Indonesia Pasca Orde Baru, Studi Tentang Pemikiran dan Gerakan, https://www.academia.edu/19759203/PERGUMULAN_ISLA M_RADIKAL_DI_INDONESIA_PASCA_ORDE_BARU_Stu di_Tentang_Pemikiran_dan_Gerakan, diakses tanggal 21/01/2020, pukul 09.14

TEMPO.co, Belajar dari Singkawang, Kota Paling Toleran 2018https://nasional.tempo.co/read/1153831/belajar-darisingkawang-kota-paling-toleran-2018/full\&view=ok diakses tanggal 21/12/2019 pukul 20:21

VOA Indonesia, SETARA Institute: Singkawang, Kota Paling Toleran Se-Indonesia, https://www.voaindonesia.com/a/setara-institutesingkawang-kota-paling-toleran-seindonesia/4690956.html, diakses tanggal 21/12/2019 pukul 20:21 